\title{
Management Strategies and Outcomes for VHL-related Craniospinal Hemangioblastomas
}

\author{
Christ Ordookhanian¹, Paul E. Kaloostian¹, Samer S. Ghostine ${ }^{1}$, Philippe E. Spiess ${ }^{2}$, Arnold B. \\ Etame $^{3^{*}}$
}

${ }^{1}$ Department of Neurological Surgery, University of California at Riverside School of Medicine, Riverside, CA, USA; ${ }^{2}$ Department of Urologic Oncology, Lee Moffitt Cancer Center and Research Institute, Tampa, FL, USA; ${ }^{3}$ Department of Neuro-Oncology, H. Lee Moffitt Cancer Center and Research Institute, Tampa, FL, USA

\begin{abstract}
Hemangioblastomas are rare and benign tumors accounting for less than $2 \%$ of all central nervous system (CNS) tumors. The vast majority of hemangioblastomas occur sporadically, whereas a small number of cases, especially in younger patients, are associated with Von Hippel-Lindau (VHL) syndrome. It is thought that loss of tumor suppressor function of the VHL gene results in stabilization of hypoxia-inducible factor alpha with downstream activation of cellular proliferative and angiogenic genes that promote tumorigenesis. VHL-related hemangioblastomas predominantly occur in the cerebellum and spine. Lesions are often diagnosed on contrast-enhanced craniospinal MRIs, and the diagnosis of VHL occurs through assessment for germline VHL mutations. Surgical resection remains the primary treatment modality for symptomatic or worrisome lesions, with excellent local control rates and neurological outcomes. Stereotactic radiotherapy can be employed in patients who are deemed high risk for surgery, have multiple lesions, or have non-resectable lesions. Given the tendency for development of either new or multiple lesions, close radiographic surveillance is often recommended for asymptomatic lesions.
\end{abstract}

Keywords: craniospinal hemangioblastoma; natural history; radiographic diagnosis; surgical resection; von Hippel-Lindau syndrome

Received: 01 July 2017; Accepted after revision: 6 August 2017; Published: 28 August 2017.

* Author for correspondence: Arnold B. Etame, Department of Neuro-Oncology, Moffitt Cancer Center and Research Institute, 12902 Magnolia Drive, Tampa, FL 33612, USA. Email: arnold.etame@moffitt.org

How to cite: Ordookhanian C et al. Management strategies and outcomes for VHL-related Craniospinal Hemangioblastomas. J Kidney Cancer VHL 2017;4(3):37-44.

DOI: http://dx.doi.org/10.15586/jkcvhl.2017.90

Copyright: Ordookhanian C et al.

License: This open access article is licensed under Creative Commons Attribution 4.0 International (CC BY 4.0). http://creativecommons.org/ licenses/by/4.0

\section{Introduction}

Hemangioblastomas (HB) are rare low-grade vascular tumors within the central nervous system (CNS) identified by the World Health Organization (WHO) criteria as Grade I tumors and account for $1-2 \%$ of CNS tumors (1). They consist of closely packed capillaries within proliferative stromal cells which form the main neoplastic component and harbor the genetic defect (2). HB can occur as solitary sporadic tumors or as multiple familial tumors associated with von HippelLindau (VHL), an autosomal dominant disorder (3). Some of the key clinical and genetic epidemiologic features of VHL syndrome are highlighted in Table 1 (4). The overwhelming 
Table 1. Epidemiology-related parameters of VHL

\begin{tabular}{|l|c|}
\hline VHL degree of incidence & 1 in 36,000 \\
\hline VHL point prevalence & 1 in 38,000 \\
\hline Age range of diagnosis (years) & Infancy to 70 \\
\hline Average age of diagnosis (years) & $26-29$ \\
\hline Average age for full penetrance of & 70 \\
\hline VHL & $1: 1$ \\
\hline Male:female penetrance & $20 \%$ \\
\hline De novo VHL mutations & $80 \%$ \\
\hline Familial VHL mutations & Presenting in \\
\hline Common clinical manifestation & VHL cases ( $\%)$ \\
\hline CNS HB & $30-80$ \\
\hline Renal cell carcinoma & $30-70$ \\
\hline Renal cysts & 60 \\
\hline Retinal angiomas & $15-70$ \\
\hline Endolymphatic sac tumors & $3-16$ \\
\hline Pancreatic cyst & $20-70$ \\
\hline Pancreatic neuroendocrine tumor & $15-56$ \\
\hline Pheochromocytoma & 16 \\
\hline
\end{tabular}

majority of $\mathrm{HB}$ occur sporadically (3). VHL-related HB arise from defects associated with loss of tumor suppression function of the VHL gene (3, 5-7). Multiple HB can be seen in at least $60 \%$ of VHL patients $(8-12)$. The most common locations for VHL-HB within the CNS include the posterior fossa and spinal cord (1). Given the locational CNS predilection, HB can be a significant source of morbidity and mortality in VHL patients. In fact, the most common cause of demise in VHL patients appears to be from posterior fossa hemorrhages associated with $\mathrm{HB}$ and also renal cell carcinoma (RCC), which is also part of the syndrome $(8,13,14)$. Surgical resection of symptomatic or radiographically progressing lesions can be curative.

\section{Pathogenesis of HB in VHL}

VHL is an autosomal dominant syndrome with age-related penetrance, characterized with over 300 germ-line mutations of the VHL gene on the short arm of chromosome 3p25 (15, 16). Deletion of a single copy of the VHL gene, also known as loss of heterozygosity, can predispose patients to the syndrome. Approximately one-third of VHL cases involve deletion mutations, whereas the remaining two-thirds are related non-deletion mutations $(15,16)$. The subsequent loss of the tumor suppressive function of VHL secondary to inactivation of both alleles has been postulated as the basis for the development of neoplasms such as HB, pheochromocytomas, and RCC in patients with VHL $(17,18)$. Although the vast majority of VHL cases have a familial genetic pattern, the syndrome can also manifest de novo without a prior family history. In a large series of 181 patients with VHL evaluated at the National Institutes of Health (NIH), 41 patients did not have a family history diagnosis of VHL suggesting a de novo manifestation (19). However, although VHL germline mutations might not be apparent when assessed by standard techniques such as Southern blot and gene sequencing, further analysis of segments of peripheral blood lymphocytes using additional molecular techniques might uncover the mutation, hence underscoring the significance of genetic mosaicism (19). It has, therefore, been postulated that parental mosaicism might account for some of the de novo or sporadic cases of VHL (19).

The main function of the VHL gene product ( $p$ VHL) is regulation through ubiquitination of hypoxia-inducible factor alpha (HIF- $\alpha)$, the major mediator of the cellular response to hypoxia (20-22). In the presence of oxygen, the proline residues of HIF- $\alpha$ are hydroxylated by prolyl hydroxylase enzymes $(20,21,23)$. The hydroxylation provides a ubiquitination tag on HIF- $\alpha$ for the VHL complex. VHL protein forms a VHL complex through interaction of its binding domains with elongation factors (elongin $\mathrm{C}$ and elongin B), and cullin-2 (20-22). Binding of the beta domain of this VHL complex with prolyl-hydroxylated HIF- $\alpha$ results in ubiquitination and degradation of HIF- $\alpha$ (24). However, prolyl-hydroxylation of HIF- $\alpha$ does not occur in hypoxic conditions $(25,26)$. As such, the VHL protein complex does not recognize and bind to HIF- $\alpha$. Similarly, defects in VHL protein complex prevent its regulation and degradation of HIF$\alpha$. Hence, it is postulated that aberrancies in VHL leading to stabilization of HIF- $\alpha$ result in downstream up-regulation of hypoxia response genes, such as vascular endothelial growth factor (VEGF) and platelet-derived growth factor (PDGF), that have a role in neoplastic transformation $(25,27,28)$.

Although genetic defects in VHL can predispose to HB in the craniospinal axis, the genetic mechanisms through which HB develop are not fully elucidated. Besides VHL mutations, germline allelic variations of several genes including CCND1, MMP1, and MMP3 have been implicated in pathogenesis of HB (29). Several studies that examined tissue expression of EGFR in HB demonstrated universally that there was an over-expression of EGFR in HB (30-32). This is not surprising because EGFR plays a role in cell proliferation and angiogenesis. A more recent large study of $44 \mathrm{HB}$ samples using droplet digital polymerase chain reaction and high-resolution single nucleotide polymorphism (SNR) arrays implicated 23 candidate in the pathogenesis of HB (33). The candidate genes included the following: EGFR, PRDM16, PTPN11, 
HOXD11, HOXD13, FLT3, PTCH, FGFR1, FOXP1, GPC3, HOXC13, HOXC11, MKL1, CHEK2, IRF4, GPHN, IKZF1, RB1, and HOXA9, and micro RNA, such as hsamir-196a-2. The most common aberrations were deletion of CHEK2 and amplifications of EGFR, PTPN11, and PTCH. In general, the genes implicated are functionally involved with cell proliferation and angiogenesis, which accounts for the highly vascular phenotype of HB.

\section{Clinical presentation}

Patients with $\mathrm{HB}$ can be asymptomatic or symptomatic based on the location and mass effects of the tumor $(3,34$, $35)$. Lesions in the posterior fossa can hemorrhage and cause obstructive hydrocephalus and associated symptoms of nausea, headaches, ataxia and profound lethargy. In extreme situations, brainstem compression with subsequent herniation has been reported (36). Moreover, even small hemorrhages in brainstem lesions can result in profound neurological symptoms. In general, symptomatic lesions were usually associated with a large cyst and brain edema (37).

Spinal HB can be asymptomatic, associated with pain, or produce myelopathic symptoms of gait impairment, paralysis, sensory deficits, bowel, and bladder dysfunction. Pain often precedes myelopathy $(38,39)$. Myelopathic symptoms are usually related to compression of long tracts with the spinal cord from tumor hemorrhage. Less commonly, patients can present with spinal subarachnoid hemorrhage $(39,40)$. Leptomeningeal dissemination of $\mathrm{HB}$ is an extremely rare presentation that has been reported in a handful of cases (41-45).

\section{Radiographic diagnosis of $\mathrm{HB}$}

HB represents one of the earliest manifestations of VHL syndrome (11). Gadolinium-enhanced magnetic resonance imaging (MRI) is the best diagnostic modality for $\mathrm{HB}$ because its resolution is markedly superior to CT $(46,47)$. They appear as homogenously enhancing lesions and are sometimes associated with a cystic component. Hemorrhage might be present. Tumors can be seen in the brainstem, cerebellum, or spinal cord (Figure 1). Spinal cord lesions can exist on the pial surface as small enhancing nodules or intramedullary with associated syrinx. Symptomatic spinal HB are often associated with syrinx and edema (48). Larger spinal $\mathrm{HB}$ are more likely associated with flow voids compared to smaller HB (48). Patients who are known to be at risk for VHL can be screened with MRI of the neural axis. Similarly, if a lesion is noted on brain MRI, then an MRI of the spine is recommended.

Alternative diagnostic modalities include contrastenhanced CT scans and angiography (49-51). CT might
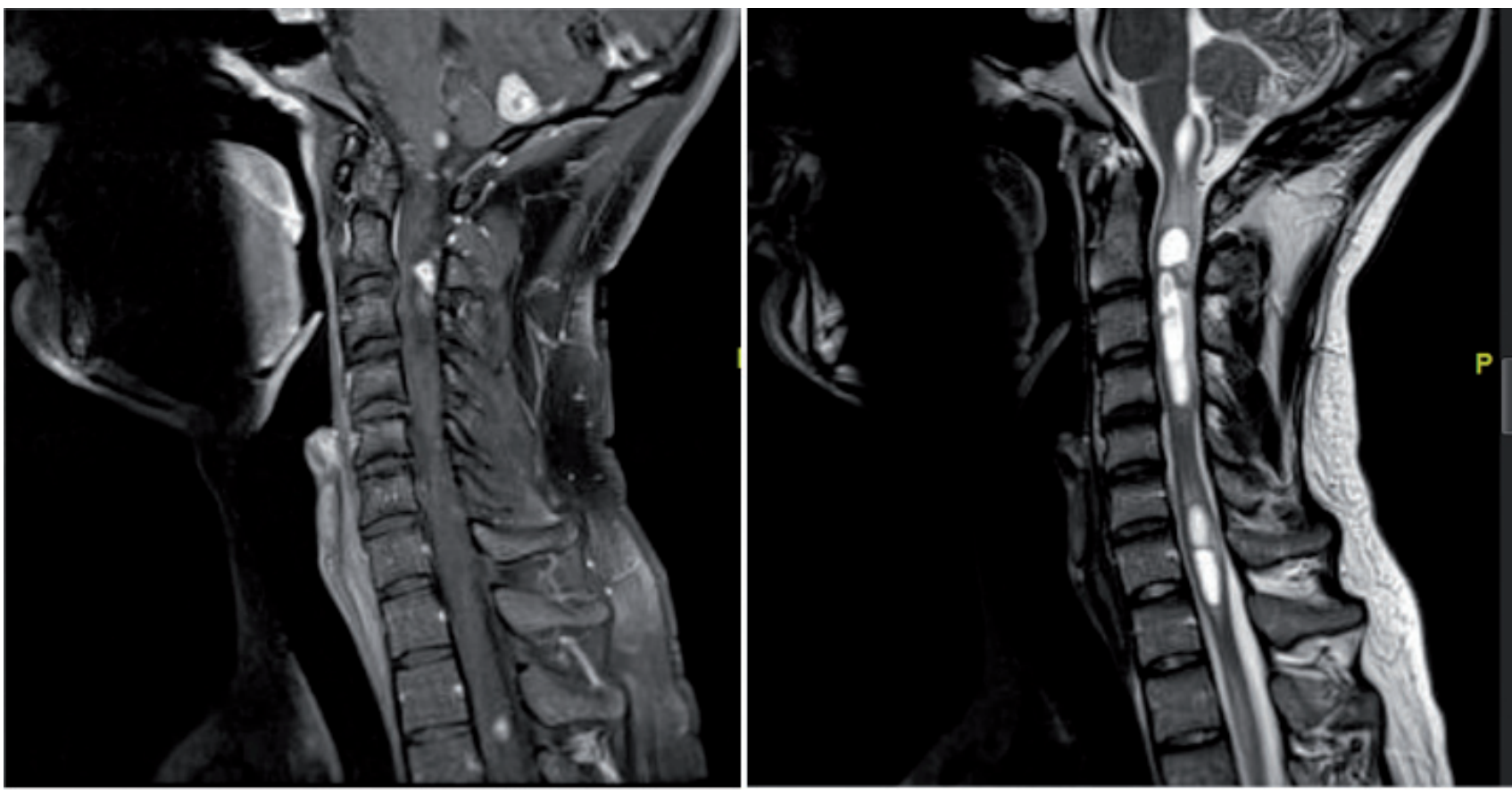

Figure 1. Sagittal MRI of posterior fossa and cervical spine. Left: T1 with gadolinium shows multiple enhancing HB tumors involving cerebellum, brainstem, and spinal cord. Right: T2 MRI shows multiple intramedullary cystic lesions consistent with VHL hemangioblastoma. 
be employed where there are contraindications to MRI. Homogenously enhancing nodules can be seen on the pial surface with CT. CT can also assess the extent of cystic compression, hemorrhage, and hydrocephalus in the case of large posterior fossa lesions. Angiography can demonstrate the classic tumor vascular blush.

\section{Natural history of HB}

Several studies have examined the natural history of $\mathrm{HB}$ as it relates to the development of symptoms and optimal timing of interventions $(1,35,52)$. Because some HB lesions might remain asymptomatic for very long periods of time, it is important to avoid unnecessary surgeries in this patient population.

Wanebo et al. retrospectively examined 160 consecutive patients with VHL through correlating clinical history with serial volumetric analysis of tumors on MRI (52). They noted a predilection of cystic lesion towards the cerebellum, spinal cord, and brainstem. Compared to the associated tumor nodule, the cysts expanded faster and were the basis for neurological symptoms as opposed to the actual tumor. What was also noteworthy was the fact that a significant number of untreated asymptomatic lesions maintained their status quo for many years. From the above study, it appears that cystic lesions should be cautiously observed and considered for treatment whenever there is substantial interval expansion with risks to vital structures.

In another retrospective study of 158 patients with VHL over a 10-year span, Ammerman and colleagues reported symptomatic lesions in only $41 \%$ of patients over that time span (1). The vast majority of lesions remained asymptomatic even with radiographic progression. The authors used clinical symptoms as opposed to radiographic progression as the basis for surgical intervention. They concluded that such an approach spared each patient from four additional unnecessary procedures over that 10 years time span.

The natural history of HB has been assessed in a prospective format as well. Lonser and colleagues prospectively enrolled 225 VHL patients with HB to assess for factors associated with tumorigenesis and neurological symptoms (53). Their assessment of increased tumors burden revealed a predilection for male sex and partial deletions in VHL gene. In addition, younger patients were most likely to develop new tumors. Furthermore, rapidly growing tumors were most likely encountered in male patients, most likely symptomatic, and associated with a cyst. Hence, the above considerations should be taken into account in the management of treatment of VHL patients with HB.

\section{Surgical resection of craniospinal HB}

Surgery is the preferred treatment modality of HB given the low morbidity of surgery. Surgery can relieve compressive neurological symptoms and can be curative. Although the role of surgery is clear for symptomatic or large lesions, surgery for asymptomatic lesions is debatable $(52,53)$. Some have advocated for treating intramedullary lesions at the onset of diagnosis as opposed to the development of neurological symptoms based on the observation that patients are least likely to improve after surgery following neurological deterioration (53-55). However, a recent prospective study on the natural history of $1921 \mathrm{CNS}$ HB in $225 \mathrm{VHL}$ patients found that the vast majority of asymptomatic lesions progressed in a stepwise fashion whereby neither absolute tumor size nor rate of tumor growth was the universal determinant of neurological symptoms (35). The authors concluded that surgery for HB should only be recommended at the onset of neurological symptoms (35).

Surgical resection of $\mathrm{HB}$ is similar to resection of any vascular malformation. Because HB are highly vascular lesions, the goal of resection entails circumferential dissection along the interface between tumor and brain without prematurely violating the tumor. Arterial feeders are circumferentially coagulated and disconnected resulting in an en-bloc resection with risks for intraoperative as well as postoperative hemorrhage. A midline myelotomy offers the safest approach that minimizes damage to the posterior columns. In some instances, preoperative embolization could be considered in order to minimize postoperative blood loss (56-58). Because spinal lesions are generally intramedullary, neurophysiologic monitoring of sensory and motor evoke potentials should be incorporated as part of the resection strategy. Similarly, lesions in the brainstem might warrant monitoring of the above modalities as well as brainstem monitoring.

As previously mentioned, surgical resection of $\mathrm{HB}$ can be curative with less morbidity at experienced centers. There are tumor-related characteristics that can significantly impact outcomes. In one study, solid tumor configuration, but not tumor size, was noted to be the key determinant of immediate or long-term postoperative outcomes in patients with cerebellar HB (59). For instance, in that study patients with solid tumors had a propensity for postoperative hematomas requiring surgical intervention. In terms of long-term outcomes, patients with solid tumors had a markedly negative outcome compared to those with solid tumors. Because solid tumors are very vascular, preoperative embolization could minimize the chances of postoperative hematomas in the posterior fossa.

Favorable outcomes have been reported for tumors in the medulla and spinal cord when the onset of symptoms was the main indication for surgical intervention. Parker and colleagues (60) reported their experience in 34 patients with $\mathrm{HB}$ and a mean age of 41 . They attained gross total tumor resection in approximately $85 \%$ of cases. There were no mortalities from surgery, and less than $18 \%$ of patients experienced worsening of symptoms following surgery. In another study of 14 patients with 15 brainstem HB lesions, Pavesi and colleagues (61) 
reported that although patients with brainstem lesions were more likely to have immediate postoperative deficits, the longterm outcomes were highly favorable. For instance, following surgery, 9 out of 14 patients experienced transient neurological deficits. However, at long-term follow-up, at least 10 patients had performance levels superior to their preoperative performance. The role of intraoperative neurophysiological monitoring (IONM) in improving outcomes during resection of spinal HB has been evaluated and emphasized (62). In a series of 24 patients who underwent surgeries for 27 lesions, the authors noted a strong correlation between a pathological IONM findings and an adverse outcome (62). On the contrary, patients who had nonpathological IONM findings were significantly less likely to have new sensorimotor deficits following surgical resection.

\section{Radiotherapy for HB}

In situations where patients are not good surgical resection candidates or where lesions are not amenable to safe resection, stereotactic radiation is a favorable option. Radiation can also be used to address multiple lesions as well as in the setting of tumor recurrence. Although not a curative strategy, it can provide reasonable and sustained local tumor control (63-68).

Kano and colleagues published one of the largest series evaluating the long-term outcomes of stereotactic radiosurgery (SRS) in the management of HB consisting of 186 patients with 517 lesions (64). They reported overall survival rates of $94 \%$ at 3 years, $90 \%$ at 5 years, and $74 \%$ at 10 years. The associated tumor control rates were $92 \%$ at 3 years, $89 \%$ at 5 years, and $79 \%$ at 10 years. Hence, excellent local control rates are feasible with SRS.

However, it is worthwhile noting that there appears to be differential response to intracranial SRS for sporadic versus VHL-related HB. In their assessment of long-term outcomes in 57 intracranial HB treated with SRS, Hanakita and colleagues reported 5- and 10-year tumor control rates of 67 and $44 \%$, respectively, for sporadic HB compared to 97 and $83 \%$, respectively, for VHL-related HB (67). Besides VHL pathology, SRS was much effective for small and solid tumors compared to large and cystic tumors.

SRS is equally effective for spinal HB in terms of halting tumor progression and improving neurological symptoms associated with HB. Pan and colleagues assessed radiographic and clinical outcomes in 34 spinal HB tumors (66). Following SRS treatment, $94 \%$ of the tumors were either stable or regressed with local control rates at 1, 3, and 5 years being 96, 92 , and $92 \%$, respectively. Symptom improvement was associated with $81 \%$ of treated lesions. Hence, SRS was deemed as a safe approach for spinal HB.

A recent systematic review comparison of retrospective data of surgical resection versus SRS for spinal HB showed that only $2 \%$ of tumors treated with SRS actually progressed (69).
SRS was associated with minimal side effects. The same study showed that surgical resection resulted in successful removal of tumor with a recurrence rate of approximately $5 \%$. It was also evident that at least $96 \%$ of patients were either clinically stable or improved on long-term follow-up from surgery. It is worthwhile noting that no statistical comparisons could be done between the surgery and SRS cohort which is a major limitation.

Overall, SRS for HB appears to be an effective alternative strategy whenever safe surgical resection is not practical. It appears to be more effective for VHL patients with HB, small tumors, and solid lesions.

\section{Conclusion}

Although HB are benign tumors, they can cause significant neurological impairment or even mortality following intratumoral hemorrhage or cystic expansion of tumor. Because the vast majority of lesions are asymptomatic with very minimal growth, observation is reasonable. Factors associated with tumor progression and treatment outcomes should be considered in the timing of interventions. Lesions that are symptomatic or demonstrate worrisome radiographic features warrant surgery resection if safely feasible. Radiosurgery remains an acceptable alternative to surgical resection. Excellent long-term outcomes can be expected with surgery and radiation.

\section{Conflict of interest}

The authors declare no potential conflicts of interest with respect to research, authorship and/or publication of this article.

\section{References}

1. Ammerman JM, Lonser RR, Dambrosia J, Butman JA, Oldfield EH. Long-term natural history of hemangioblastomas in patients with von Hippel-Lindau disease: Implications for treatment. J Neurosurg. 2006;105(2):248-55. http://dx.doi. org/10.3171/jns.2006.105.2.248

2. Vortmeyer AO, Gnarra JR, Emmert-Buck MR, Katz D, Linehan WM, Oldfield EH, et al. von Hippel-Lindau gene deletion detected in the stromal cell component of a cerebellar hemangioblastoma associated with von Hippel-Lindau disease. Hum Pathol. 1997;28(5):540-3. http://dx.doi.org/10.1016/ S0046-8177(97)90075-7

3. Neumann HP, Eggert HR, Weigel K, Friedburg H, Wiestler OD, Schollmeyer P. Hemangioblastomas of the central nervous system. A 10-year study with special reference to von Hippel-Lindau syndrome. J Neurosurg. 1989;70(1):24-30. http:// dx.doi.org/10.3171/jns. 1989.70.1.0024

4. Chittiboina P, Lonser RR. Von Hippel-Lindau disease. Handb Clin Neurol. 2015;132:139-56. http://dx.doi.org/10.1016/ B978-0-444-62702-5.00010-X

5. Kanno H, Kondo K, Ito S, Yamamoto I, Fujii S, Torigoe S, et al. Somatic mutations of the von Hippel-Lindau tumor suppressor 
gene in sporadic central nervous system hemangioblastomas. Cancer Res. 1994;54(18):4845-7.

6. Lee JY, Dong SM, Park WS, Yoo NJ, Kim CS, Jang JJ, et al. Loss of heterozygosity and somatic mutations of the VHL tumor suppressor gene in sporadic cerebellar hemangioblastomas. Cancer Res. 1998;58(3):504-8.

7. Glasker S, Bender BU, Apel TW, van Velthoven V, Mulligan LM, Zentner J, et al. Reconsideration of biallelic inactivation of the VHL tumour suppressor gene in hemangioblastomas of the central nervous system. J Neurol Neurosurg Psychiatry. 2001;70(5):644-8. http://dx.doi.org/10.1136/jnnp.70.5.644

8. Maher ER, Yates JR, Harries R, Benjamin C, Harris R, Moore AT, et al. Clinical features and natural history of von Hippel-Lindau disease. Q J Med. 1990;77(283):1151-63. http://dx. doi.org/10.1093/qjmed/77.2.1151

9. Filling-Katz MR, Choyke PL, Oldfield E, Charnas L, Patronas NJ, Glenn GM, et al. Central nervous system involvement in Von Hippel-Lindau disease. Neurology. 1991;41(1):41-6. http:// dx.doi.org/10.1212/WNL.41.1.41

10. Lamiell JM, Salazar FG, Hsia YE. von Hippel-Lindau disease affecting 43 members of a single kindred. Medicine (Baltimore). 1989;68(1):1-29. http://dx.doi. org/10.1097/00005792-198901000-00001

11. Maddock IR, Moran A, Maher ER, Teare MD, Norman A, Payne SJ, et al. A genetic register for von Hippel-Lindau disease. J Med Genet. 1996;33(2):120-7. http://dx.doi.org/10.1136/ jmg.33.2.120

12. Neumann HP, Eggert HR, Scheremet R, Schumacher M, Mohadjer M, Wakhloo AK, et al. Central nervous system lesions in von Hippel-Lindau syndrome. J Neurol Neurosurg Psychiatry. 1992;55(10):898-901. http://dx.doi.org/10.1136/jnnp.55.10.898

13. Butman JA, Linehan WM, Lonser RR. Neurologic manifestations of von Hippel-Lindau disease. JAMA. 2008;300(11): 1334-42. http://dx.doi.org/10.1001/jama.300.11.1334

14. Wilding A, Ingham SL, Lalloo F, Clancy T, Huson SM, Moran A, et al. Life expectancy in hereditary cancer predisposing diseases: An observational study. J Med Genet. 2012;49(4):264-9. http://dx.doi.org/10.1136/jmedgenet-2011-100562

15. Barontini M, Dahia PL. VHL disease. Best Pract Res Clin Endocrinol Metab. 2010;24(3):401-13. http://dx.doi.org/10.1016/j. beem.2010.01.002

16. Safo AO, Pambuccian SE. Pancreatic manifestations of von HippelLindau disease. Arch Pathol Lab Med. 2010;134(7):1080-3.

17. Foster K, Crossey PA, Cairns P, Hetherington JW, Richards $\mathrm{FM}$, Jones $\mathrm{MH}$, et al. Molecular genetic investigation of sporadic renal cell carcinoma: Analysis of allele loss on chromosomes 3p, 5q, 11p, 17 and 22. Br J Cancer. 1994;69(2):230-4. http://dx.doi.org/10.1038/bjc.1994.44

18. Crossey PA, Foster K, Richards FM, Phipps ME, Latif F, Tory $\mathrm{K}$, et al. Molecular genetic investigations of the mechanism of tumourigenesis in von Hippel-Lindau disease: Analysis of allele loss in VHL tumours. Hum Genet. 1994;93(1):53-8. http://dx. doi.org/10.1007/BF00218913

19. Sgambati MT, Stolle C, Choyke PL, Walther MM, Zbar B, Linehan WM, et al. Mosaicism in von Hippel-Lindau disease: Lessons from kindreds with germline mutations identified in offspring with mosaic parents. Am J Hum Genet. 2000;66(1): 84-91. http://dx.doi.org/10.1086/302726

20. Calzada MJ. Von Hippel-Lindau syndrome: Molecular mechanisms of the disease. Clin Transl Oncol. 2010;12(3):160-5. http://dx.doi.org/10.1007/s12094-010-0485-9

21. Pause A, Lee S, Worrell RA, Chen DY, Burgess WH, Linehan WM, et al. The von Hippel-Lindau tumor-suppressor gene product forms a stable complex with human CUL-2, a member of the Cdc53 family of proteins. Proc Natl Acad Sci U S A. 1997;94(6):2156-61. http://dx.doi.org/10.1073/pnas.94.6.2156

22. Pause A, Peterson B, Schaffar G, Stearman R, Klausner RD. Studying interactions of four proteins in the yeast two-hybrid system: Structural resemblance of the $\mathrm{pVHL} /$ elongin $\mathrm{BC} /$ hCUL-2 complex with the ubiquitin ligase complex SKP1/cullin/ F-box protein. Proc Natl Acad Sci U S A. 1999;96(17):9533-8. http://dx.doi.org/10.1073/pnas.96.17.9533

23. Brinke A, Green PM, Giannelli F. Characterization of the gene (VBP1) and transcript for the von Hippel-Lindau binding protein and isolation of the highly conserved murine homologue. Genomics. 1997;45(1):105-12. http://dx.doi.org/10.1006/ geno. 1997.4902

24. Ivan M, Kondo K, Yang H, Kim W, Valiando J, Ohh M, et al. HIFalpha targeted for VHL-mediated destruction by proline hydroxylation: Implications for $\mathrm{O} 2$ sensing. Science. 2001;292(5516):464-8. http://dx.doi.org/10.1126/science.1059817

25. Iliopoulos O, Levy AP, Jiang C, Kaelin WG Jr., Goldberg MA. Negative regulation of hypoxia-inducible genes by the von Hippel-Lindau protein. Proc Natl Acad Sci USA. 1996;93(20):10595-9. http://dx.doi.org/10.1073/pnas.93. 20.10595

26. Jaakkola P, Mole DR, Tian YM, Wilson MI, Gielbert J, Gaskell SJ, et al. Targeting of HIF-alpha to the von Hippel-Lindau ubiquitylation complex by O2-regulated prolyl hydroxylation. Science. 2001;292(5516):468-72. http://dx.doi.org/10.1126/ science. 1059796

27. Gnarra JR, Zhou S, Merrill MJ, Wagner JR, Krumm A, Papavassiliou E, et al. Post-transcriptional regulation of vascular endothelial growth factor mRNA by the product of the VHL tumor suppressor gene. Proc Natl Acad Sci USA. 1996;93(20):10589-94. http://dx.doi.org/10.1073/ pnas.93.20.10589

28. Kim WY, Kaelin WG. Role of VHL gene mutation in human cancer. J Clin Oncol. 2004;22(24):4991-5004. http://dx.doi. org/10.1200/JCO.2004.05.061

29. Ricketts C, Zeegers MP, Lubinski J, Maher ER. Analysis of germline variants in CDH1, IGFBP3, MMP1, MMP3, STK15 and VEGF in familial and sporadic renal cell carcinoma. PLoS One. 2009;4(6):e6037. http://dx.doi.org/10.1371/journal. pone. 0006037

30. Chen GJ, Karajannis MA, Newcomb EW, Zagzag D. Overexpression and activation of epidermal growth factor receptor in hemangioblastomas. J Neurooncol. 2010;99(2):195-200. http:// dx.doi.org/10.1007/s11060-010-0125-9

31. Bohling T, Hatva E, Kujala M, Claesson-Welsh L, Alitalo K, Haltia M. Expression of growth factors and growth factor receptors in capillary hemangioblastoma. J Neuropathol Exp Neurol. 1996;55(5):522-7. http://dx.doi. org/10.1097/00005072-199605000-00004

32. Reifenberger G, Reifenberger J, Bilzer T, Wechsler W, Collins VP. Coexpression of transforming growth factor-alpha and epidermal growth factor receptor in capillary hemangioblastomas of the central nervous system. Am J Pathol. 1995;147(2):245-50.

33. Mehrian-Shai R, Yalon M, Moshe I, Barshack I, Nass D, Jacob J, et al. Identification of genomic aberrations in hemangioblastoma by droplet digital PCR and SNP microarray highlights novel candidate genes and pathways for pathogenesis. BMC Genomics. 2016;17:56. http://dx.doi.org/10.1186/ s12864-016-2370-6

34. de la Monte SM, Horowitz SA. Hemangioblastomas: Clinical and histopathological factors correlated with recurrence. 
Neurosurgery. 1989;25(5):695-8. http://dx.doi.org/10.1227/ 00006123-198911000-00002

35. Lonser RR, Butman JA, Huntoon K, Asthagiri AR, Wu T, Bakhtian KD, et al. Prospective natural history study of central nervous system hemangioblastomas in von Hippel-Lindau disease. J Neurosurg. 2014;120(5):1055-62. http://dx.doi. org/10.3171/2014.1.JNS131431

36. Wakai S, Inoh S, Ueda Y, Nagai M. Hemangioblastoma presenting with intraparenchymatous hemorrhage. J Neurosurg. 1984;61(5):956-60. http://dx.doi.org/10.3171/jns.1984.61.5.0956

37. Jagannathan J, Lonser RR, Smith R, DeVroom HL, Oldfield EH. Surgical management of cerebellar hemangioblastomas in patients with von Hippel-Lindau disease. J Neurosurg. 2008;108(2):210-22. http://dx.doi.org/10.3171/ JNS/2008/108/2/0210

38. Sharma GK, Kucia EJ, Spetzler RF. Spontaneous intramedullary hemorrhage of spinal hemangioblastoma: Case report. Neurosurgery. 2009;65(3):E627-8; discussion E8.

39. Gluf WM, Dailey AT. Hemorrhagic intramedullary hemangioblastoma of the cervical spinal cord presenting with acute-onset quadriparesis: Case report and review of the literature. J Spinal Cord Med. 2014;37(6):791-4. http://dx.doi.org/10. 1179/2045772314Y.0000000210

40. Kormos RL, Tucker WS, Bilbao JM, Gladstone RM, Bass AG. Subarachnoid hemorrhage due to a spinal cord hemangioblastoma: Case report. Neurosurgery. 1980;6(6):657-60. http://dx. doi.org/10.1227/00006123-198006000-00009

41. Bakshi R, Mechtler LL, Patel MJ, Lindsay BD, Messinger S, Gibbons KJ. Spinal leptomeningeal hemangioblastomatosis in von Hippel-Lindau disease: Magnetic resonance and pathological findings. J Neuroimaging. 1997;7(4):242-4. http://dx.doi. org/10.1111/jon199774242

42. Courcoutsakis NA, Prassopoulos PK, Patronas NJ. Aggressive leptomeningeal hemangioblastomatosis of the central nervous system in a patient with von Hippel-Lindau disease. AJNR Am J Neuroradiol. 2009;30(4):758-60. http://dx.doi.org/10.3174/ ajnr.A1360

43. Ramachandran R, Lee HS, Matthews B, Shatzel A, Tihan T. Intradural extramedullary leptomeningeal hemangioblastomatosis and paraneoplastic limbic encephalitis diagnosed at autopsy: An unlikely pair. Arch Pathol Lab Med. 2008;132(1):104-8.

44. Reyns N, Assaker R, Louis E, Lejeune JP. Leptomeningeal hemangioblastomatosis in a case of von Hippel-Lindau disease: Case report. Neurosurgery. 2003;52(5):1212-15; discussion 5-6.

45. Koo HW, Park JE, Cha J, Kim DJ, Kang SG, Lim SC, et al. Hemangioblastomas with leptomeningeal dissemination: Case series and review of the literature. Acta Neurochir (Wien). 2016;158(6):1169-78. http://dx.doi.org/10.1007/ s00701-016-2798-0

46. Filling-Katz MR, Choyke PL, Patronas NJ, Gorin MB, Barba D, Chang R, et al. Radiologic screening for von Hippel-Lindau disease: The role of Gd-DTPA enhanced MR imaging of the CNS. J Comput Assist Tomogr. 1989;13(5):743-55. http://dx. doi.org/10.1097/00004728-198909000-00001

47. Guhl L, Mironov A, Schroth G. Contribution of MRI in the diagnosis of haemangioblastomas. J Neurol. 1987;235(2):95-8. http://dx.doi.org/10.1007/BF00718017

48. Chu BC, Terae S, Hida K, Furukawa M, Abe S, Miyasaka K. MR findings in spinal hemangioblastoma: Correlation with symptoms and with angiographic and surgical findings. AJNR Am J Neuroradiol. 2001;22(1):206-17.

49. Seeger JF, Burke DP, Knake JE, Gabrielsen TO. Computed tomographic and angiographic evaluation of hemangioblastomas.
Radiology. 1981;138(1):65-73. http://dx.doi.org/10.1148/ radiology.138.1.7192875

50. O'Reilly GV, Rumbaugh CL, Bowens M, Kido DK, Naheedy MH. Supratentorial haemangioblastoma: The diagnostic roles of computed tomography and angiography. Clin Radiol. 1981;32(4):389-92. http://dx.doi.org/10.1016/ S0009-9260(81)80276-0

51. Pinto JA, Pereira JR, Guimaraes A, Veiga-Pires JA. The value of CT-scanning in supratentorial haemangioblastomas. Neuroradiology. 1987;29(6):573-5. http://dx.doi.org/10.1007/ BF00350445

52. Wanebo JE, Lonser RR, Glenn GM, Oldfield EH. The natural history of hemangioblastomas of the central nervous system in patients with von Hippel-Lindau disease. J Neurosurg. 2003;98(1):82-94. http://dx.doi.org/10.3171/jns.2003.98.1.0082

53. Lonser RR, Weil RJ, Wanebo JE, DeVroom HL, Oldfield EH. Surgical management of spinal cord hemangioblastomas in patients with von Hippel-Lindau disease. J Neurosurg. 2003;98(1):106-16. http://dx.doi.org/10.3171/jns.2003.98.1.0106

54. Joaquim AF, Ghizoni E, dos Santos MJ, Valadares MG, da Silva FS, Tedeschi H. Intramedullary hemangioblastomas: Surgical results in 16 patients. Neurosurg Focus. 2015;39(2):E18. http://dx.doi.org/10.3171/2015.5.FOCUS15171

55. Cristante L, Herrmann HD. Surgical management of intramedullary hemangioblastoma of the spinal cord. Acta Neurochir (Wien). 1999;141(4):333-9; discussion 9-40. http://dx.doi. org $/ 10.1007 / \mathrm{s} 007010050308$

56. Horvathy DB, Hauck EF, Ogilvy CS, Hopkins LN, Levy EI, Siddiqui AH. Complete preoperative embolization of hemangioblastoma vessels with Onyx 18. J Clin Neurosci. 2011;18(3):401-3. http://dx.doi.org/10.1016/j.jocn.2010.06.016

57. Murai Y, Kominami S, Yoshida Y, Mizunari T, Adachi K, Koketsu K, et al. Preoperative liquid embolization of cerebeller hemangioblastomas using N-butyl cyanoacrylate. Neuroradiology. 2012;54(9):981-8. http://dx.doi.org/10.1007/ s00234-011-0985-5

58. Sakamoto N, Ishikawa E, Nakai Y, Akutsu H, Yamamoto T, Nakai K, et al. Preoperative endovascular embolization for hemangioblastoma in the posterior fossa. Neurol Med Chir (Tokyo). 2012;52(12):878-84. http://dx.doi.org/10.2176/ nmc. 52.878

59. Fukuda M, Takao T, Hiraishi T, Yoshimura J, Yajima N, Saito A, et al. Clinical factors predicting outcomes after surgical resection for sporadic cerebellar hemangioblastomas. World Neurosurg. 2014;82(5):815-21. http://dx.doi.org/10.1016/j. wneu.2014.06.018

60. Parker F, Aghakhani N, Ducati LG, Yacubian-Fernandes A, Silva MV, David P, et al. Results of microsurgical treatment of medulla oblongata and spinal cord hemangioblastomas: A comparison of two distinct clinical patient groups. J Neurooncol. 2009;93(1):133-7. http://dx.doi.org/10.1007/s11060-009-9861-0

61. Pavesi G, Berlucchi S, Munari M, Manara R, Scienza R, Opocher G. Clinical and surgical features of lower brain stem hemangioblastomas in von Hippel-Lindau disease. Acta Neurochir (Wien). 2010;152(2):287-92. http://dx.doi.org/10.1007/ s00701-009-0512-1

62. Siller S, Szelenyi A, Herlitz L, Tonn JC, Zausinger S. Spinal cord hemangioblastomas: Significance of intraoperative neurophysiological monitoring for resection and long-term outcome. J Neurosurg Spine. 2017;26(4):483-93. http://dx.doi.org/10.317 1/2016.8.SPINE16595

63. Kano H, Niranjan A, Mongia S, Kondziolka D, Flickinger JC, Lunsford LD. The role of stereotactic radiosurgery for 
intracranial hemangioblastomas. Neurosurgery. 2008;63(3): 443-50; discussion 50-1.

64. Kano H, Shuto T, Iwai Y, Sheehan J, Yamamoto M, McBride HL, et al. Stereotactic radiosurgery for intracranial hemangioblastomas: A retrospective international outcome study. J Neurosurg. 2015;122(6):1469-78. http://dx.doi.org/10.3171/2014.10. JNS131602

65. Puataweepong P, Dhanachai M, Hansasuta A, Dangprasert S, Sitathanee C, Puddhikarant P, et al. The clinical outcome of intracranial hemangioblastomas treated with linac-based stereotactic radiosurgery and radiotherapy. J Radiat Res. 2014;55(4):761-8. http://dx.doi.org/10.1093/jrr/rrt235

66. Pan J, Ho AL, D'Astous M, Sussman ES, Thompson PA, Tayag AT, et al. Image-guided stereotactic radiosurgery for treatment of spinal hemangioblastoma. Neurosurg
Focus. 2017;42(1):E12. http://dx.doi.org/10.3171/2016.10. FOCUS16361

67. Hanakita S, Koga T, Shin M, Takayanagi S, Mukasa A, Tago $\mathrm{M}$, et al. The long-term outcomes of radiosurgery for intracranial hemangioblastomas. Neuro Oncol. 2014;16(3):429-33. http://dx.doi.org/10.1093/neuonc/not201

68. Smalley SR, Schomberg PJ, Earle JD, Laws ER Jr., Scheithauer BW, O'Fallon JR. Radiotherapeutic considerations in the treatment of hemangioblastomas of the central nervous system. Int J Radiat Oncol Biol Phys. 1990;18(5):1165-71. http://dx.doi. org/10.1016/0360-3016(90)90454-R

69. Bridges KJ, Jaboin JJ, Kubicky CD, Than KD. Stereotactic radiosurgery versus surgical resection for spinal hemangioblastoma: A systematic review. Clin Neurol Neurosurg. 2017;154: 59-66. http://dx.doi.org/10.1016/j.clineuro.2017.01.012 